\title{
ASPEK PERPAJAKAN YANG BERKAITAN DENGAN PENGGUNAAN DANA DESA
}

\author{
Galih Wicaksono \\ galih.fisip@unej.ac.id \\ Universitas Jember
}

\begin{abstract}
This study aims to describe what types of taxes are related to the use of village funds. This research is a qualitative descriptive study and uses the library method in analyzing data. Based on the Law General Provisions and Tax Procedures regulate that taxpayers are individuals or entities, including taxpayers, tax cutters, and tax collectors who have tax rights and obligations in accordance with the provisions of tax laws and regulations. Funds that enter the village are sourced from the APBN or APBD, of course, in practice the implementation will be tax payable according to the type of transaction. Therefore the Village Head and the Village Devices, especially the Village Treasurer must understand and know well and correctly. The village treasurer must know and understand some types of taxes that are owed in each transaction, as well as the rights and obligations that must be carried out related to taxes in the village, for example the NPWP filing obligation, PPh 21 collection, PPh 22, PPh 23, Income Tax 4 (2), VAT, and Stamp Duty. Armed with a good understanding of the types of transactions and taxes owed, it is expected that the practice of taxation in the village is in accordance with applicable laws and regulations.
\end{abstract}

Keywords: Treasurer, Taxation, Village Fund

\begin{abstract}
ABSTRAK
Penelitian ini bertujuan untuk mendeskripsikan jenis pajak apa saja yang berkaitan dengan penggunaan dana desa. Penelitian ini merupakan penelitian deskriptif kualitatif dan menggunakan metode kepustakaan dalam menganalisis data. Berdasarkan Undang-Undang Ketentuan Umum dan Tatacara Perpajakan mengatur bahwa wajib pajak adalah orang pribadi atau badan, meliputi pembayar pajak, pemotong pajak, dan pemungut pajak yang mempunyai hak dan kewajiban perpajakan sesuai dengan ketentuan peraturan perundang-undangan perpajakan. Dana yang masuk ke desa yang bersumber dari APBN maupun APBD, tentu saja dalam praktek pelaksanaannya akan terutang pajak sesuai dengan jenis transaksinya. Oleh karena itu Kepala Desa beserta Perangkat Desa, khususnya Bendahara Desa harus memahami dan mengetahui dengan baik dan benar. Bendahara desa harus mengetahui dan memahami dengan baik beberapa jenis pajak yang terutang dalam setiap transaksi, serta hak dan kewajiban yang harus dilaksanakan terkait pajak yang ada di desa, misalkan kewajiban pengajuan NPWP, kewajiban pemotongan atau pemungutan PPh 21, PPh 22, PPh 23, PPh 4 (2), PPN, serta Bea Materai. Dengan berbekal pemahaman yang baik mengenai jenis transaksi dan pajak yang terutang, diharapkan praktek perpajakan di desa sesuai dengan Undang-undang dan peraturan yang berlaku.
\end{abstract}

Kata Kunci : Bendahara, Perpajakan, Dana Desa 


\section{PENDAHULUAN}

Desa adalah kesatuan masyarakat hukum yang memiliki batas wilayah yang berwenang untuk mengatur dan mengurus urusan pemerintahan, kepentingan masyarakat setempat berdasarkan prakarsa masyarakat, hak asal-usul, dan / atau hak tradisional yang diakui dan dihormati dalam sistem pemerintahan Negara Kesatuan Republik Indonesia (Permendagri No.113 Tahun 2014). Desa dalam pengertian umum adalah sebagai suatu gejala yang bersifat universal, terdapat dimanapun di dunia ini, sebagai suatu komunitas kecil, terikat pada lokalitas tertentu baik sebagai tempat tinggal maupun bagi pemenuhan kebutuhannya, terutama tergantung pada sektor pertanian (Indrizal, 2006). Kemajuan sebuah negara pada dasarnya sangat ditentukan oleh kemajuan desa, karena tidak ada negara yang maju tanpa provinsi yang maju, tidak ada provinsi yang maju tanpa kabupaten dan kota yang maju, dan tidak ada kabupaten dan kota yang maju tanpa desa dan kelurahan yang maju. Ini berarti basis kemajuan sebuah negara ditentukan oleh kemajuan desa (Soleh dan Rochmansjah, 2015).

\section{Desa mempunyai sumber} pendapatan berupa pendapatan asli desa, bagi hasil pajak daerah dan retribusi daerah kabupaten / kota, bagian dari dana perimbangan keuangan pusat dan daerah yang diterima oleh kabupaten / kota, serta hibah dan sumbangan yang tidak mengikat dari pihak ketiga (UU No. 6 Tahun 2014). Sumber pendapatan desa tersebut secara keseluruhan digunakan untuk mendanai seluruh kewenangan yang menjadi tangggungjawab desa. Dana tersebut digunakan untuk mendanai penyelenggaraan kewenangan desa yang mencakup penyelenggaraan pemerintahan,

pembangunan, pemberdayaan masyarakat, dan kemasyarakatan. Dengan demikian, pendapatan desa yang bersumber dari APBN juga digunakan untuk mendanai kewenangan tersebut.

Dana desa adalah dana
yang bersumber dari APBN yang diperuntukkan bagi desa yang ditransfer oleh pemerintah pusat melalui APBD kabupaten / kota. Dana desa harus dikelola secara tertib, taat pada ketentuan peraturan perundangundangan, efisien, ekonomis, efektif, transparan, dan bertanggungjawab dengan memperhatikan rasa keadilan dan kepatutan serta mengutamakan kepentingan masyarakat setempat (PP No. 60 Tahun 2014). Seperti diketahui, desa diberikan kewenangan untuk mengatur dan mengurus kewenangannya sesuai dengan kebutuhan dan prioritas desa. Ini artinya dana desa akan digunakan untuk mendanai keseluruhan kewenangan desa sesuai dengan kebutuhan dan prioritas dan desa tersebut. Dengan tata kelola keuangan desa yang baik, maka akan terciptalah desa yang mandiri dan akhirnya akan mencapai pembangunan Indonesia yang lebih maksimal 
(Sujarweni, 2015).

Sesuai dengan ketentuan peraturan perundang-undangan, bahwa kepala desa, bendahara desa, beserta perangkat desa lainnya sebagai pelaksana teknis bertanggungjawab terhadap pengelolaan keuangan desa. Dalam pengelolaan keuangan desa tersebut, bendahara desa bertugas dalam urusan penatausahaan. Artinya bahwa kepala desa dalam melaksanakan penatausahaan keuangan desa harus menetapkan bendahara desa. Penetapan bendahara desa harus dilakukan sebelum dimulainya tahun anggaran bersangkutan dan berdasarkan keputusan kepala desa. Bendahara adalah perangkat desa yang ditunjuk oleh kepala desa untuk menerima, menyimpan, menyetorkan, menatausahakan, membayar, dan mempertanggungjawabkan keuangan desa dalam rangka pelaksanaan APBDesa (Hamzah, 2015).

Bendahara desa adalah unsur staf sekretariat desa yang membidangi urusan administrasi keuangan untuk menatausahakan keuangan desa. Bendahara desa merupakan bagian dari pengelola teknis pengelolaan keuangan desa (PTPKD). PTPKD merupakan unsur perangkat desa yang membantu kepala desa untuk melaksanakan pengelolaan keuangan desa. Bendahara desa dijabat oleh staf urusan keuangan. Bendahara desa wajib melakukan pencatatan setiap penerimaan dan pengeluaran serta melakukan tutup buku setiap akhir bulan secara tertib. Bendahara desa wajib mempertanggungjawabkan uang melalui laporan pertanggungjawaban. Laporan pertanggungjawaban tersebut disampaikan setiap bulan kepada kepala desa paling lambat tanggal 10 bulan berikutnya.

Berkaitan dengan adanya beberapa transaksi penggunaan dana desa yang ada di setiap wilayah desa, pemahaman tentang pajak harus lebih ditingkatkan seiring dengan adanya perkembangan transaksi ekonomi. Setiap transaksi ekonomi selalu dapat dikaitkan dengan aspek pengenaan pajak, baik yang dilakukan oleh pelaku usaha maupun dilakukan oleh perangkat instansi pemerintah yang dananya bersumber dari APBN / APBD. Selain itu, adanya beberapa sumber dana yang berasal dari kabupaten / kota dan provinsi, maka aspek perpajakan hendaknya harus benar-benar diperhatikan oleh segenap perangkat desa. Adanya belanja barang dan jasa dari perangkat desa, akan menggiatkan sektor ekonomi di pedesaan dan meningkatkan omzet para pelaku usaha, otomatis meningkatkan jmlah wajib pajak dan penerimaan pajak untuk negara.

Seperti diketahui bahwa pihak yang berperan dalam melaksanakan fungsi perbendaharaan dan fungsi pemungutan pajak dalam pengelolaan APBN / APBD adalah bendahara satuan kerjanya. Demikian pula di desa, bendaha desa adalah yang melaksanakan pengeluaran anggaran yang dananya 
bersumber dari APBN / APBD memiliki kewajiban untuk memungut / memotong, menyetor, dan melaporkan pajak atas transaksi yang timbul di desa. Aparatur desa memiliki tanggungjawab untuk mengamankan penerimaan negara sesuai dengan ketentuan peraturan perundang-undangan perpajakan. Potensi perpajakan yang terkait dengan alokasi dana desa ini sangat bervariasi, tergantung dari jenis transaksi yang merupakan obyek pajak, serta transaksi atas pengadaan barang / jasa yang dapat dikenakan pajak (www. pajak.go.id).

\section{Memang disadari bahwa} masih banyak desa yang melakukan pembangunan fisik / konstruksi masih menggunakan sistem swakelola, sehingga ada saja terdapat pembelian material-material yang merupakan bukan barang kena pajak, sedangkan pembayaran tenaga kerjanya menggunakan cara upah harian atau borongan. Hal demikian tentu saja akan merepotkan bendahara desa dalam menghitung pajak terutang maupun untuk mengidentifikasi jenis barang yang merupakan obyek pajak atau bukan. Selain hal tersebut, banyak bendahara desa yang masih kebingungan dalam menentukan jenis pajak, obyek pajak, dan wajib pajak dalam beberapa transaksi. Kebingungan itu menyebabkan kadang bendahara desa salah dalam penentuan tarif pajak yang seharusnya dipungut atau dipotong, yang tentu saja hal ini akan mengakibatkan kerugian bagi penerimaan negara. Lebih lanjut, menurut Wicaksono dan Pamungkas (2017) perpajakan terbagi menjadi dua, yaitu pajak pusat dan pajak daerah, dimana pajak daerah terdapat pajak provinsi dan pajak kabupaten atau kota.

Berdasarkan beberapa hal yang telah dijelaskan di atas, sangat dipandang perlu bagi aparatur desa pada umumnya, serta bendahara desa pada khususnya, untuk mendapatkan pengetahuan yang memadai berkaitan dengan aspek perpajakan dalam transaksi yang berkaitan dengan penggunaan dana desa. Hal ini agar tidak terjadi kesalahan dalam pemungutan, pemotongan, penyetoran, dan pelaporan dalam aspek perpajakan yang berkaitan dengan transaksi penggunaan dana desa. Dengan adanya pengetahuan yang mendalam tentang perpajakan dalam penggunaan dana desa, akan membantu negara dalam penerimaan pajak. Oleh karena itu, diharapkan bagi aparatur desa pada umumnya, serta bendahara desa pada khususnya, untuk menguasai aspek-aspek perpajakan yang berkaitan dengan penggunaan dana desa.

\section{METODE PENELITIAN}

Penelitian ini merupakan jenis penelitian kepustakaan atau yang biasa disebut dengan studi pustaka. Menurut Mahmud(2011), penelitian kepustakaan adalah merupakan suatau penelitian yang dilakukan dengan cara membaca buku atau majalah dan beberapa sumber yang lain untuk mengumpulkan data dari berbagai macam jenis literatur, yang diperoleh dari perpustakaan 


\section{EKOMBIS sains}

maupun tempat-tempat lain yang memungkinkan peneliti dapat memperoleh data secara memadai. Alasan peneliti melakukan penelitian kepustakaan hal ini dikarenakan agar dapat memotret secara utuh gambaran kewajiban perpajakan apa saja yang melekat pada penggunaan dana desa, sehingga diharapkan hasil penelitian ini bermanfaat bagi pihak-pihak yang berkepentingan.

Pendekatan dalam penelitian ini menggunakan pendekatan kualitatif. Hal ini dikarenakan sumber data dan hasil penelitian yang berupa uraian katakata yang berasal dari studi kepustakaan. Sumber data pada penelitian ini berupa Undang-Undang Pajak, Peraturan Pajak, buku referensi pajak, serta internet. Teknik pengumpulan data pada penelitian ini dengan menggunakan teknik dokumentasi, yaitu cara-cara yang dilakukan peneliti dan mengumpulkan dan menggali data yang bersumber dari beberapa sumber, baik berupa sumber data primer maupun sekunder. Peneliti menggunakan teknik dokumentasi karena penelitian ini merupakan penelitian kepustakaan, yang sumber datanya dari undang-undang pajak, peraturan pajak, buku referensi, serta interenet.

Tahapan yang dilakukan oleh peneliti antara lain : 1) mengumpulkan bahan penelitian, 2) membaca bahan pustaka, 3) membuat catatan secara umum, 4) membuat catatan khusus, 5) mengolah hasil catatan, 6) menulis hasil penelitian, dan 7) menyimpulkan hasil penelitian. Sedangkan untuk teknik analisis data yang dilakukan oleh peneliti meliputi : 1) analisis isi, 2) analisis induktif, dan 3) analisis deskriptif. Dengan adanya beberapa tahapan dan teknik analisis data seperti yang telah disebutkan di atas, diharapkan penelitian ini dapat menghasilkan temuan-temuan yang akurat terkait aspek perpajakan yang berkaitan dengan penggunaan dana desa.

\section{PEMBAHASAN}

Pada tahun 2014, dana desa menjadi bahasan politik yang akhirnya direalisasikan dalam bentuk UndangUndang Desa yaitu UU No. 6 Tahun 2014 Tentang Desa. Dana desa yang bergulir ke kas desa tentu harus dikelola sebaik mungkin dan perorangan yang ditunjuk sebagai bendahara desa harus memahami fungsinya sebagai juru bayar dan juga wajib pungut yang bertugas menghitung, memotong / memungut, menyetor, dan melaporkan pajak atas pembelanjaan dana desa tersebut. Oleh karena prinsip pajak di Indonesia yang menganut self assesment system, maka bendahara desa diberikan tanggungjawab dan kepercayaan untuk melaksanakan kewajiban perpajakannya. Namun tidak sedikit bendahara desa yang kebingungan dan tidak memahami aturan-aturan yang berkaitan dengan perpajakan. Berikut ini akan diuraikan berkaitan dengan perpajakan yang berkaitan dengan penggunaan dana desa.

1. Mendaftarkan diri untuk 
mendapatkan NPWP

Nomor pokok wajib pajak (NPWP) merupakan suatu sarana dalam administrasi perpajakan yang dipergunakan sebagai tanda pengenal diri atau identitas wajib pajak. NPWP dipergunakan untuk menjaga ketertiban dalam pembayaran pajak dan pengawasan administrasi perpajakan. Pendaftaran NPWP bisa dilakukan melalui kantor pelayanan pajak (KPP) atau melalui elektronik secara online pada alamat www. pajak.go.id dengan mengklik menu e-registration. Kewajiban dasar sebagai wajib pajak / wajib pungut yaitu memiliki NPWP. NPWP yang didaftarkan adalah NPWP atas nama desa / bendahara desa. Perorangan yang ditunjuk sebagai bendahara desa tentunya harus memiliki NPWP pribadi dan atas NPWP bendahara desa. Persyaratan yang harus dilengkapi untuk memiliki NPWP bendahara desa adalah fotokopi surat penunjukan sebagai bendahara desa, serta fotokopi KTP bendahara yang bersangkutan, kemudian mengisi formulir pendaftaran NPWP bendahara (Resmi, 2014).

2. PPh Pasal 21

Pajak yang dipotong oleh bendahara desa yang berkaitan dengan pembayaran gaji, upah, honorarium, bonus, insentif atau pembayaran lain kepada orang pribadi. Termasuk di dalamnya adalah atas pembayaran kepada individu bendahara desa itu sendiri, apabila telah melebihi batasan penghasilan tidak kena pajak (PTKP), maka bendahara desa wajib memotong pajak untuk dirinya sendiri. Apabila si penerima penghasilan tidak memiliki NPWP, maka akan dipotong PPh Pasal 21 dengan tarif $20 \%$ lebih tinggi dari pajak yang seharusnya dipotong. Secara umum, beberapa jenis penghasilan yang dipotong PPh Pasal 21 oleh desa adalah sebagai berikut (UU No. 36 Tahun 2008 tentang Pajak Penghasilan) :

a. penghasilan yang diterima pegawai tetap (bersifat teratur maupun tidak teratur),

b. penghasilan pegawai tidak tetap atau tenaga kerja lepas (upah harian, upah mingguan, upah satuan, upah borongan, atau upah yang dibayarkan secara bulanan),

c. imbalan kepada bukan pegawai (honorarium, komisi, fee, dan imbalan sehubungan dengan pekerjaan / jasa / kegiatan),

d. imbalan kepada peserta kegiatan (uang saku, uang representasi, uang rapat, honorarium, hadiah atau penghargaan, dan imbalan yang sejenis),

e. penghasilan berupa jasa produksi, tantiem, gratifikasi, bonus, atau imbalan lain yang bersifat tidak teratur yang diterima oleh mantan pegawai,

f. penghasilan berupa honorarium , uang perangsang, uang hadir, dan imbalan lain dengan nama apapun yang diterima oleh pejabat negara, PNS, TNI, POLRI, yang sumber 
dananya berasal dari keuangan negara atau keuangan daerah, kecuali yang dibayarkan kepada PNS golongan II/d ke bawah dan anggota TNI / POLRI berpangkat pembantu letnan satu ke bawah atau ajun inspektur tingkat satu ke bawah.

\section{PPh Pasal 22}

Pajak yang dipungut dari pihak ketiga (pengusaha/toko) oleh bendahara desa dalam hal pembayaran / pembelian barang dengan nilai diatas Rp 2.000.000,- (dua juta rupiah) dan bukan transaksi yang terpecahpecah. Tarifnya adalah 1,5\% dari dasar pengenaan pajak apabila pihak ketiga tersebut (pengusaha/toko) memiliki NPWP, sedangkan apabila tidak memiliki NPWP maka tarifnya menjadi $3 \%$. Secara umum, beberapa jenis kegiatan di desa yang dikenakan $\mathrm{PPh}$ Pasal 22 adalah sebagai berikut (UU No. 36 Tahun 2008 tentang Pajak Penghasilan) :

a. Pembayaran atas pembelian barang yang dilakukan oleh bendahara desa,

b. Pembayaran atas pembelian barang yang dilakukan dengan mekanisme uang persediaan oleh bendahara,

c. Pembayaran atas pembelian barang kepada pihak ketiga yang dilakukan dengan mekanisme pembayaran langsung.
Pajak yang dipotong dari penghasilan yang diterima rekanan atas sewa (tidak termasuk sewa tanah dan atau bangunan), serta imbalan jasa manajemen, jasa teknik, jasa konsultan, dan jasa lainnya. Tarifnya untuk penghasilan atas jasa adalah 2 $\%$ jika rekanan ber NPWP, jika belum punya NPWP dipotong $4 \%$. Secara umum, penghasilan yang dikenakan pemotongan $\mathrm{PPh}$ Pasal 23 oleh desa antara lain sebagai berikut (UU No. 36 Tahun 2008 tentang Pajak Penghasilan) :

a. Sewa dan penghasilan lain sehubungan dengan penggunaan harta, kecuali sewa dan penghasilan lain sehubungan dengan penggunaan harta yang telah dikenai Pajak Penghasilan sebagaimana dimaksud dalam PPh Pasal 4 ayat (2) Final, tarif 2 $\%$.

b. Imbalan sehubungan dengan jasa teknik, jasa manajemen, jasa konstruksi, jasa konsultan, dan jasa lain selain jasa yang telah dipotong PPh Pasal 21, tarif $2 \%$.

5. PPh Pasal 4 Ayat (2) Final Pajak yang dipotong atas pembayaran : sewa tanah dan atau bangunan, pengalihan hak atas tanah dan atau bangunan, jasa konstruksi (perencana, pelaksana, dan pengawas). Beberapa transaksi yang dilakukan oleh desa yang dapat dilakukan pemotongan $\mathrm{PPh}$ Pasal 4 ayat (2) Final antara lain sebagai berikut (UU No. 36 Tahun 2008 
tentang Pajak Penghasilan) :

a. Persewaan tanah dan atau bangunan, tarif $10 \%$.

b. Jasa konstruksi, meliputi: perencanaan konstruksi, pelaksanaan konstruksi, dan pengawasan konstruksi, tarif antara $2 \%-6 \%$ sesuai kualifikasi usaha.

c. Wajib pajak yang usaha pokoknya melakukan pengalihan hak atas tanah dan atau bangunan, tarif 5 $\%$.

6. Pajak Pertambahan Nilai (PPN) PPN merupakan pemungutan pajak atas pembelian barang / jasa kena pajak yang jumlah nominalnya di atas Rp 1.000.000,- (satu juta rupiah) dan tidak merupakan pembayaran yang terpecah-pecah. Tarif PPN adalah $10 \%$ dari dasar pengenaan pajak (harga tidak termasuk PPN). Bendahara desa sangat dianjurkan memilih rekanan yang sudah menjadi pengusaha kena pajak (PKP) dan sudah menerbitkan nomor seri faktur pajak. Rekanan diusahakan harus PKP, karena hanya rekanan yang ber-PKP yang bisa menerbitkan faktur pajak. Jika dalam transaksi tidak menggunakan rekanan yang ber-PKP, maka PPN tetap dipungut oleh bendahara desa, akan tetapi untuk pertanggungjawaban administrasinya kurang lengkap, dikarenakan tidak ada faktur pajak. Hal ini tentu saja akan menjadi temuan bagi inspektorat yang terkait.

Berkaitan dengan pengenaan
PPN, pada intinya yang dikenakan PPN adalah barang kena pajak (BKP) dan jasa kena pajak (JKP). Secara umum, semua jenis barang adalah BKP, dan setiap jenis jasa adalah JKP, kecuali yang dinyatakan oleh Undang-Undang No. 42 / 2009 tentang PPN bahwa barang tersebut bukan BKP (non-BKP) dan bukan JKP (non-JKP). Berikut ini adalah jenis barang dan jasa yang termasuk nonBKP dan non-JKP, atau tidak kena PPN dalam transaksinya (UU No. 42 Tahun 2009 tentang Pajak Pertambahan Nilai) : a. Barang Tidak Kena PPN (Non-BKP)

1. Barang hasil pertambangan atau hasil pengeboran yang diambil langsung dari sumbernya,

2. Barang kebutuhan pokok yang sangat dibutuhkan oleh rakyat banyak,

3. Makanan dan minuman yang disajikan di hotel, restoran, rumah makan, warung, dan sejenisnya, meliputi makanan dan minuman baik yang dikonsumsi di tempat maupun tidak, termasuk makanan dan minuman yang diserahkan oleh usaha jasa boga atau katering,

4. Uang, emas batangan, dan surat berharga.

b. Jasa Tidak Kena PPN (Non-JKP)

1. Jasa pelayanan kesehatan medis,

2. Jasa pelayanan sosial,

3. Jasa pengiriman surat dengan prangko,

4. Jasa keuangan,

5. Jasa asuransi,

6. Jasa keagamaan,

7. Jasa pendidikan,

8. Jasa kesenian dan hiburan, 


\section{EKOMBIS sains}

9. Jasa penyiaran yang tidak bersifat iklan,

10. Jasa angkutan umum di darat dan di air, serta jasa angkutan udara dalam negeri yang menjadi bagian tidak terpisahkan jasa angkutan udara luar negeri,

11. Jasa tenaga kerja,

12. Jasa perhotelan,

13. Jasa yang disediakan oleh pemerintah dalam rangka menjalankan pemerintahan secara umum,

14. Jasa penyediaan tempat parkir,

15. Jasa telepon umum dengan menggunakan uang logam,

16. Jasa pengiriman uang dengan wesel pos,

17. Jasa boga atau katering.

Jadi secara umum, barang dan jasa yang tidak termasuk kategori Non-BKP dan Non-JKP, semuanya akan terutang PPN yang harus dipungut oleh bendahara desa.

\section{Bea Materai}

Bea materai adalah pajak yang dikenakan atas suatu dokumen. Dokumen adalah kertas yang berisikan tulisan yang mengandung arti dan maksud tentang perbuatan, keadaan, atau kenyataan bagi seseorang dan atau pihak-pihak yang berkepentingan. Benda materai adalah materai tempel dan kertas materai yang dikeluarkan oleh Pemerintah Republik Indonesia. Tarif materai terbagi menjadi dua, yaitu materai nominal Rp 3.000,- dan
Rp 6.000,- (UU No. 13 Tahun 1985 tentang Bea Materai). Ketentuan pemateraian di desa adalah sebagai berikut :

a. Apabila desa membuat suatu dokumen yang menyebutkan nilai nominal di atas $\mathrm{Rp} 250.000 .000$,sampai dengan Rp 1.000.000,maka dokumen tersebut hendaknya dikenakan materai sebesar Rp 3.000,-.

b. Sedangkan apabila dokumen tersebut menyebutkan nilai nominal di atas Rp 1.000.000,, dan atau terdapat dampak hukum di masa mendatang bagi desa, maka dokumen tersebut dikenakan materai sebesar $\mathrm{Rp}$ $6.000,-$.

\section{KESIMPULAN}

Berdasarkan pembahasan yang telah dilakukan, maka dapat ditarik kesimpulan bahwa perpajakan yang berkaitan dengan penggunaan dana desa adalah sebagai berikut ini :

1. Bendahara desa wajib mendaftarkan diri untuk memperoleh NPWP ke Kantor Pelayanan Pajak (KPP) setempat, dengan persyaratan yang harus dipenuhi adalah : fotokopi surat penunjukan sebagai bendahara desa dan fotokopi KTP bendahara desa yang bersangkutan.

2. PPh Pasal 21, merupakan pajak yang dipotong oleh bendahara desa yang berkaitan dengan pembayaran : gaji, upah, honorarium, komisi, fee, imbalan peserta kegiatan, bonus, uang hadir, dan imbalan lain dalam 
bentuk apapun yang diberikan kepada orang pribadi.

3. PPh Pasal 22, dipungut dari pihak ketiga / rekanan dalam hal pembelian barang / jasa dengan nilai di atas Rp 2.000.000,- dan bukan transaksi yang dipecah-pecah.

4. $\mathrm{PPh}$ Pasal 23, dipotong dari penghasilan yang diterima rekanan atas sewa (tidak termasuk sewa tanah dan atau bangunan), serta imbalan atas jasa manajemen, jasa teknik, jasa konsultan, dan jasa lainnya, selain yang telah dipotong PPh Pasal 21.

5. PPh Pasal 4 ayat (2) Final, dipotong atas pembayaran sewa tanah dan atau sewa bangunan, jasa konstruksi (perencana konstruksi, pelaksana konstruksi, pengawas konstruksi), dan wajib pajak yang usaha pokoknya melakukan pengalihan hak atas tanah dan atau bangunan.

6. PPN, dipungut atas pembelian barang / jasa kena pajak yang jumlah nilai nominalnya di atas Rp 1.000.000,- Pada intinya semua barang / jasa kena PPN, kecuali beberapa jenis / barang atau jasa yang termasuk NonBKP (Bukan Barang Kena Pajak) dan Non-JKP (Bukan Jasa Kena Pajak).

7. Bea Materai, merupakan pajak yang dikenakan atas dokumen. Apabila suatu dokumen menyebut nilai nominal di atas $\mathrm{Rp} 250.000$,sampai dengan Rp 1.000.000,- maka dikenakan materai $\mathrm{Rp}$ 3.000,-. Sedangkan apabila dokumen dengan nilai nominal di atas Rp1.000.000,-, maka dikenakan materai $\mathrm{Rp} 6.000$,-

\section{SARAN}

Berdasarkan pembahasan dan kesimpulan di atas tentang perpajakan yang berkaitan dengan penggunaan dana desa, maka dapat disarankan sebagai berikut :

1. Untuk Pemerintah Desa, hendaknya selalu memperhatikan dan update informasi berkaitan dengan peraturan pajak yang berhubungan dengan penggunaan dana desa. Hal ini agar pemerintah desa selalu mengetahui dan mematuhi peraturan pajak, sehingga bisa turut mengamankan potensi penerimaan negara, serta tidak menjadi temuan yang menyimpang apabila ada audit dari inspektorat.

2. Untuk Pemerintah Kabupaten / Kota, hendaknya selalu memberikan sosialisasi dan bimbingan secara berkala kepada desa-desa yang ada di bawah naungannya yang berkaitan dengan pajak. Pemerintah Kabupaten / Kota juga hendaknya bisa mengawasi ketertiban dalam administrasi pajak yang ada di desa, sehingga dapat meminimalisir kesalahan yang berkaitan dengan aspek perpajakan penggunaan dana desa.

3. Untuk Kantor Pelayanan Pajak (KPP), hendaknya apabila ada update peraturan pajak terbaru yang berkaitan dengan penggunaan dana desa, bisa menginformasikan kepada setiap desa di wilayahnya dengan cara mengirim selebaran panduan yang berisi aturan dan tatacara perhitungan, pemotongan / 


\section{EKOMBIS sains}

pemungutan, dan penyetoran pajak yang harus dilakukan oleh bendahara desa. Sehingga bendahara desa akan dapat menyesuaikan peraturan pajak yang baru dengan efektif.

\section{DAFTAR PUSTAKA}

Hamzah, Ardi. 2015. Tata Kelola Pemerintahan Desa Menuju Desa Mandiri, Sejahtera, Parsipatoris. Penerbit Mustaka Jawa Timur.

Mahmud. 2011. Metode Penelitian

Pendidikan. CV Pustaka Setia Bandung.

Indirizal, Edi. 2006. Tipologi Desa di Indonesia.

Resmi, Siti. 2014. Perpajakan : Teori dan Kasus. Penerbit Salempa Empat Jakarta.

Sujarweni, V. Wiratna. 2015. Akuntansi

Desa. Pustaka Baru Press

Yogyakarta.

Soleh, Chabib dan Heru Rochmansjah. 2015. Pengelolaan Keuangan Desa. Penerbit Fokusmedia Bandung.

Peraturan Menteri Dalam Negeri Republik Indonesia No. 113 Tahun 2014 tentang Pengelolaan Keuangan Desa.

Peraturan Pemerintah Republik Indonesia No. 60 Tahun 2014 tentang Dana Desa Yang Bersumber Dari Anggaran Pendapatan Dan Belanja Negara. Undang - Undang Republik Indonesia No. 6 Tahun 2014 tentang Desa.

Undang - Undang Republik Indonesia

No. 28 Tahun 2007 tentang

Ketentuan Umum dan Tatacara
Perpajakan.

Undang - Undang Republik Indonesia No. 36 Tahun 2008 tentang Pajak Penghasilan.

Undang - Undang Republik Indonesia No. 42 Tahun 2009 tentang Pajak Pertambahan Nilai.

Wicaksono, Galih dan Tree Setiawan Pamungkas. 2017. Analisis Efektivitas dan Kontribusi Pajak Bumi dan Bangunan Perdesaan dan Perkotaan (PBB P2) terhadap Pendapatan Asli Daerah (PAD) Kabupaten Jember. Jurnal STIE Semarang, Vol.9, No.1, Februari 2017.

www.google.co.id www.pajak.go.id www.pemeriksaanpajak.com 